\title{
Urgences
}

\section{Un soir, le grondement des essuie-glaces}

\section{Louise Beauchamp}

Numéro 15, octobre 1986

Épigraphiques

URI : https://id.erudit.org/iderudit/025317ar

DOI : https://doi.org/10.7202/025317ar

Aller au sommaire du numéro

Éditeur(s)

Urgences

ISSN

0226-9554 (imprimé)

1927-3924 (numérique)

Découvrir la revue

Citer ce document

Beauchamp, L. (1986). Un soir, le grondement des essuie-glaces. Urgences, (15),

52-52. https://doi.org/10.7202/025317ar

Ce document est protégé par la loi sur le droit d'auteur. L’utilisation des services d’Érudit (y compris la reproduction) est assujettie à sa politique d'utilisation que vous pouvez consulter en ligne.

https://apropos.erudit.org/fr/usagers/politique-dutilisation/
Cet article est diffusé et préservé par Érudit.

Érudit est un consortium interuniversitaire sans but lucratif composé de l’Université de Montréal, l'Université Laval et l'Université du Québec à Montréal. Il a pour mission la promotion et la valorisation de la recherche. https://www.erudit.org/fr/ 


\section{Louise Beauchamp UN SOIR, LE GRONDEMENT DES ESSUIE- GLACES}

Chaque soir, des cigales venaient, des cerisiers, se jeter dans la maison.

Yasunari Kawabata: Le grondement de la montagne

Le silence entre eux, ne pas le briser

la nuit, déjà, tombe

nostalgique, elle s'étire.

Elle aimait tant la musique chaque soir, elle s'assoyait au piano, inlassablement des élèves venaient, quelquefois.

Un cauchemar l'a peut-être tuée. Une pluie tombe il allume une cigarette elle ouvre la fenêtre, un peu.

La nuit sera fraîche

l'automne approche, encore écho d'un train

se rapprochant, au loin.

Les essuie-glaces

de leurs mouvements effacent toutes images possibles. 